\title{
THE EFFECT OF HIGHER ORDER THINKING SKILLS (HOTS) LEARNING MODELS ON THE ABILITY TO WRITE DESCRIPTION THROUGH INTERACTIVE MEDIA IN SD NEGERI 114361 BINANGA DUA LABUHANBATU SELATAN
}

\author{
Rendra Parluhutan Hutapea ${ }^{1}$ \\ Open University, Indonesia \\ E-mail : rendraparluhutanhutape2003@gmail.com \\ Rosmawaty ${ }^{2}$ \\ Open University, Indonesia \\ E-mail : rosmawaty@gmail.com \\ Sri Listyarini ${ }^{3}$ \\ Open University, Indonesia \\ E-mail : sri.listyarini@gmail.com
}

\begin{abstract}
This type of research is an experiment using pre test and post test control group design. The purpose of this study was to determine the effect of the ability to write descriptions on the Higher Order Thinking Skill (HOTS) Learning Model through interactive media in class VI SD Negeri 114361 Binanga Dua. This research was conducted at SD Negeri 114361 Binaga Dua. Which is located in Binaga Dua District, South Labuhanbatu Regency and its implementation is in the first semester of the 2019/2020 Academic Year. The population in this study were all grade VI students of SD Negeri 114361 Binaga Two academic year 2019/2020, which consisted of 2 classes with a total of 56 students. The sample in this study using purposive sampling. Of the 2 classes that have the same level of mastery, the total sample is selected, where the VIA class is the experimental class with 28 students and the VIB class is the control class with 28 students. Learning Indonesian using the Higher Order Thinking Skills (HOTS) learning model through interactive media can improve the students ability to write descriptions of SD Negeri 114361 Binanga Dua, South Labuhanbatu Regency. There is an average
\end{abstract}


difference in the results of the ability to write descriptions of Indonesian using the HOTS learning model and compared to conventional learning models through interactive media in grade VI SD Negeri 114361 Binanga Dua, South Labuhanbatu Regency It can be concluded that there is an effect of HOTS learning on students ability to write descriptions through interactive media at SD Negeri 114361 Binanga Dua Labuhanbatu Selatan.

Keywords: Higher Order Thinking Skill (HOTS) Learning Model, Descriptive Writing Ability, Interactive Media.

\section{A. Intoduction}

The Indonesian language subject is one of the subjects in schools which is considered to play an important role in shaping students to become quality. Teaching Indonesian is the process of teaching or teaching Indonesian, with the main objective being to enable students to communicate in Indonesian. Many factors cause the low level and lack of understanding of students about the concept of learning, one of which is the learning model used by the teacher. A learning model that is suitable for students where students participate in sharing these knowledge, concepts, skills to students who need it and each student feels happy to develop his knowledge to other members of the group. The low quality of this learning is caused by various reasons.

Trianto (2010) states that based on the results of research on the low learning outcomes of students, this is due to the learning process which is dominated by traditional learning. In this learning, the classroom atmosphere tends to be teacher-centered so that students become passive. Furthermore, Usman (in Desmayani, 2010) states that many factors cause students lack of understanding of the Indonesian language, one of which is the learning method or model used by the teacher. For example in learning-oriented traditional approaches that place students in 
the teaching and learning process as listeners. On the other hand, the role of the teacher / teacher in learning is very dominant.

According to Komaruddin (in Trianto 2010: 2) states that "One of the changes in the learning paradigm is the orientation of learning from being teacher centered to being student centered; the methodology that was previously dominated by expository has changed to participatory; and the approach that was originally more textual has turned into contextual. All these changes are intended to improve the quality of education, both in terms of educational processes and outcomes".

One learning model that activates students in the learning process is the High Order Thinking Skills (HOTS) learning model. HOTS Learning Model emphasizes creative problem solving skills. This means that in HOTS learning, there is the ability to think creatively or high order thinking that can be seen. Students can exercise the ability to think creatively by choosing problems and developing responses, because in solving problems that are passed through the thinking process will lead to creativity. Karimah (2018) suggests that Higher Order Thinking Skill (HOTS) is a student's thinking skill in obtaining new information stored in their memory, then connecting and conveying it for the expected purpose.

The general picture shows that the learning outcomes of SD Negeri 114361 Binanga Dua Labuhanbatu Selatan are still low in the Indonesian language field of study because the teacher does not vary the learning models in the teaching and learning process, the lack of breadth of ideas for students in writing an essay, the lack of creativity of teachers using interactive media In learning, the teacher teaches the same method or the teacher dominates the teaching and learning process, this can be seen from the results of students learning through the final evaluation that the learning outcomes obtained by students are still low. 
Researchers are interested in doing this research because the HOTS learning model has never been used by teachers at SD Negeri 114361 Binanga Dua, teachers need to use attractive media to support learning description writing skills, besides this media can be used to clarify messages, for limited space if the object is too major and lessons regarding events in the past. In addition, through picture media students can translate abstract ideas into more realistic forms. The use of media in learning to write descriptions can clarify concepts and attract students attention.

Based on the description above the researcher is interested in conducting a research with the title: "The Effect of High Order Thinking Skill (HOTS) Learning Model Assisted by Interactive Media on the Ability to Write Descriptions in SD Negeri 114361 Binanga Dua Labuhanbatu Selatan."

\section{B. Method}

\section{Types of research}

This type of research is an experiment using pre-test and post-test control group design. The design forms of this research are:

Table 1. Research Design

\begin{tabular}{ccc}
\hline Pretest & Treatment & Postes \\
\hline $\mathrm{T} 1$ & $\mathrm{X} 1$ & $\mathrm{~T} 2$ \\
\hline $\mathrm{T} 1$ & $\mathrm{X} 2$ & $\mathrm{~T} 2$ \\
\hline
\end{tabular}

Source: Sugiyono (2013: 116) has been adjusted to the needs of the research

Information:

T1 : Pretest ability to write descriptions before students are taught using HOTS and conventional learning models through interactive media 
T2 : PTest the ability to write descriptions after students are taught using HOTS and conventional learning models through interactive media

X1 : HOTS learning model

X2 : Conventional Learning Model

\section{Resources}

Population and research sample

This research was conducted at SD Negeri 114361 Binaga Dua. Which is located in Silangkitang District, South Labuhanbatu Regency and its implementation in the first semester of the 2019/2020 Academic Year. The population in this study were all grade VI students of SD Negeri 114361 Binaga Two academic year 2019/2020, which consisted of 2 classes with a total of 56 students. The sample in this study using purposive sampling. Of the 2 classes that have the same level of mastery, the total sample is selected, where the VIA class is the experimental class with 28 students and the VIB class is the control class with 28 students.

Research Variables

The variables in this study are as follows.

Independent Variable : Learning model Higher Order Thinking Skills (HOTS) and conventional learning models through interactive media

Dependent variable $\quad:$ Interactive writing skills

\section{Research Instruments}

The research instrument was a test in the form of a description, amounting to 5 questions. The validators in this study were Indonesian teachers and school principals 


\section{Finding and Discussion}

\section{Result}

Obtaining research results based on the formulation of the problem is described as follows.

a. There is an influence of the HOTS learning model through interactive media on the ability to write descriptions.

This is evidenced by the results of the hypothesis test that the Sig. $(2$-tailed $)$ value is $=0.001 ;(0.001<0.05)$ means that $\mathrm{Ho}$ is rejected and $\mathrm{Ha}$ is accepted, that is, there is an effect of HOTS learning on students ability to write descriptions. High-order thinking processes or by using Higher Order Thinking Skills (HOTS) learning models through interactive media are a sequence of mental events that occur naturally or are planned and systematically in the context of space, time, and the media used, and produce a change in the objects that influence them. The thought process is an event of mixing, matching, combining, exchanging, and ordering concepts, perceptions, and previous experiences (Kuswana, 2013: 3).

b. The ability to write descriptions of students who are taught using the HOTS model is better than those taught by conventional learning through interactive media.

This is evidenced by the average results of students description writing skills taught using the HOTS model is 78.75 , while the average results of students description writing skills taught using conventional models are lower, namely $63.04<78.75$. This proves that the ability to write descriptions of students who are taught using the HOTS model is better than using the conventional model. Learning in the conventional model, students listen more to the teacher's explanation either directly or in the context of students being invited to take notes 
or make summaries and carry out assignments given by the teacher in the form of practice questions to students. The conventional learning model usually uses the lecture method, the question and answer method, the discussion method, and the assignment method. Sukandi (2001), defines that the conventional learning model is characterized by the teacher teaching more roles or teaching about concepts not competencies, the goal is that students know something is not able to do something and during the learning process students listen more. Here it can be seen that the conventional approach referred to is the learning process which is dominated by the teacher as a "transfer of knowledge, while students are more passive as" recipients "of knowledge.

c. There are differences in the ability to write descriptions using the HOTS learning model and conventional learning models through interactive media.

Based on the results of hypothesis testing 1 and 2 above, it can be concluded that there are differences in the ability to write descriptions using the HOTS learning model and the conventional learning model through interactive media. The application of the HOTS learning model in addition to improving students writing skills, this model can also improve learning outcomes. The learning outcomes obtained by students from the learning activities they do, these results are a form of evidence of someone's treatment or involvement in carrying out their learning efforts. This means that the higher the involvement of students in writing descriptions, the better the learning outcomes. Whereas conventional learning models can be understood as learning that is more teacher-centered, more one-way communication from teacher to student, 


\section{Discussion}

Results of Pretest and Posttest

Before the research was carried out, for students who were taught using the HOTS learning model, an average score or mean $(=63.04$, variance $(=96.925$; standard deviation $(s)=9.845)$ was obtained. The highest score obtained was 80 and the lowest score obtained was obtained. is 45 , while for students who are taught with the conventional learning model, the average or mean score is obtained $(=64.29$, variance ( $=112.434$; standard deviation $(s)=10.603$. The highest score obtained is 80 and the lowest score obtained is $\left.45 . \bar{x}) s^{2}\right) \bar{x}$ ) $s^{2}$ )

The posttest score was obtained for the HOTS learning model, the average score or mean $(=78.75$, variance $(=104.861$; standard deviation $(s)=10.24$. The highest score obtained was 100 and the lowest score obtained was 60 , while for students who were taught with conventional learning models, obtained an average score or mean $(=68.39$, variance $(=$ 127.877; standard deviation $(s)=11.308$. The highest score obtained was 90 and the lowest score obtained was $45 . \bar{x}$ ) $\left.s^{2}\right) \bar{x}$ ) $s^{2}$ )

data on the prettest value of students taught by conventional learning models with a value of 45 as many as 2 people, a value of 50 as many as 3 people, a value of 55 as many as 3 people, a value of 60 as many as 3 people, a value of 65 as many as 5 people, a value of 70 as many as 5 people, a value of 75 as many 4 people and a score of 80 as many as 3 people. The following is a diagram of the prettest scores: 


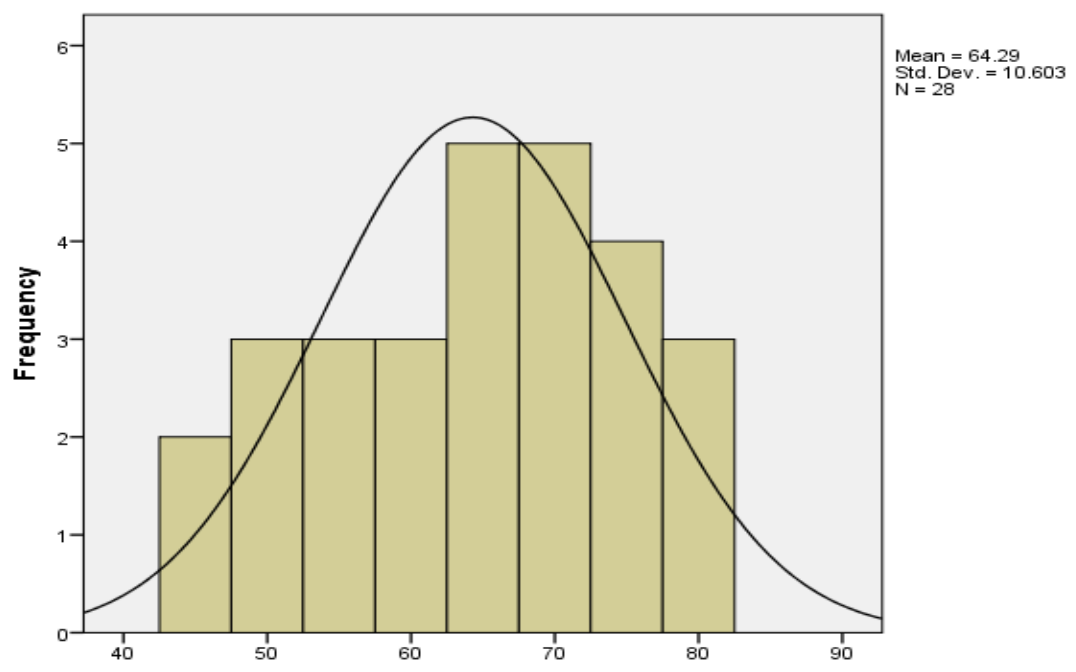

Figure 1. Diagram of Students Prettest Values taught by Conventional Learning Model

Posttest value data of students taught by conventional learning models with a value of 45 as much as 1 person, a value of 50 as much as 2 people, a value of 55 as many as 2 people, a value of 60 as many as 3 people, a value of 65 as many as 4 people, a value of 70 as many as 6 people, a value of 75 as many 4 people, 3 points for 80,2 for 85 , and 1 for 90 The student posttest score diagram is as follows. 


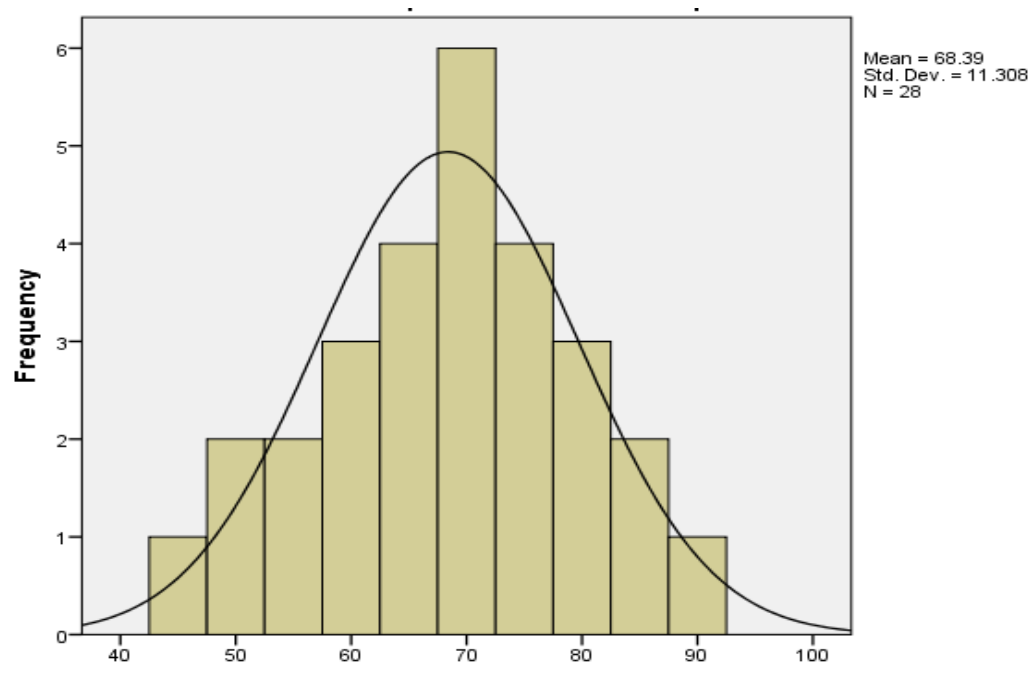

Figure 2. Student Posttest Diagram using Conventional Learning Model

Data on the prettest value of students who were taught using the HOTS learning model with a value of 45 as many as 2 people, a value of 50 as many as 3 people, a value of 55 as many as 3 people, a value of 60 as many as 4 people, a value of 65 as many as 7 people, a value of 70 as many as 4 people, a value of 75 as many 3 people, 2 people scored 80, 2 people scored 85 , and 1 person scored 90 . The following is a diagram of the results of the acquisition of students prettest scores taught using the HOTS learning model. 


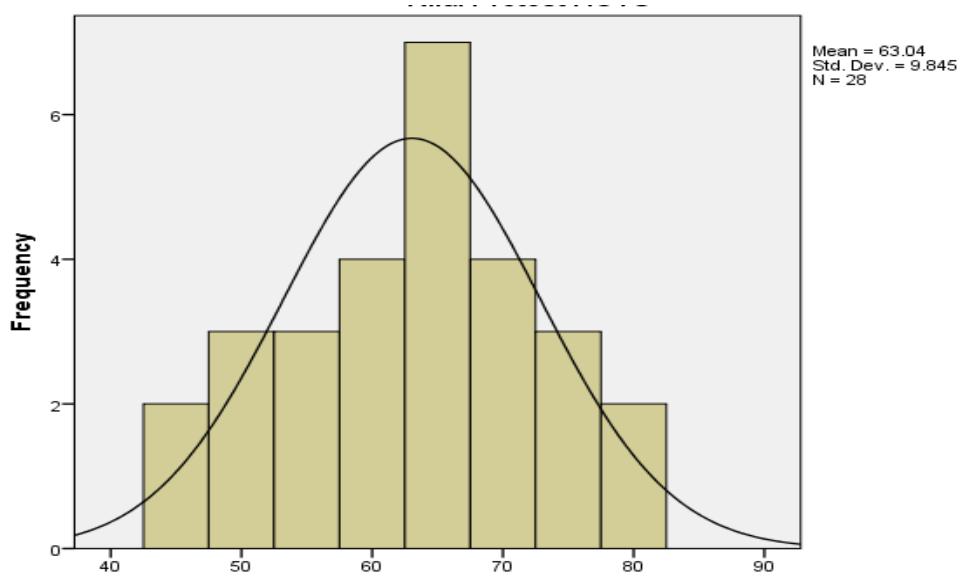

Figure 3. Diagram of Students Pretest Values using the HOTS Learning Model

Data on the posttest scores of students who were taught using the HOTS learning model with a value of 60 as many as 1 person, a value of 65 as many as 3 people, a value of 70 as many as 4 people, a value of 75 as many as 6 people, a value of 80 as many as 4 people, a value of 85 as many as 4 people, a value of 90 as many 3 people, 2 people scored 95, and 1 person scored 100. The following is the table data for the post-test scores of students who are taught using the HOTS learning model:

The following is a diagram of the results of the acquisition of posttest scores of students taught using the HOTS learning model: 


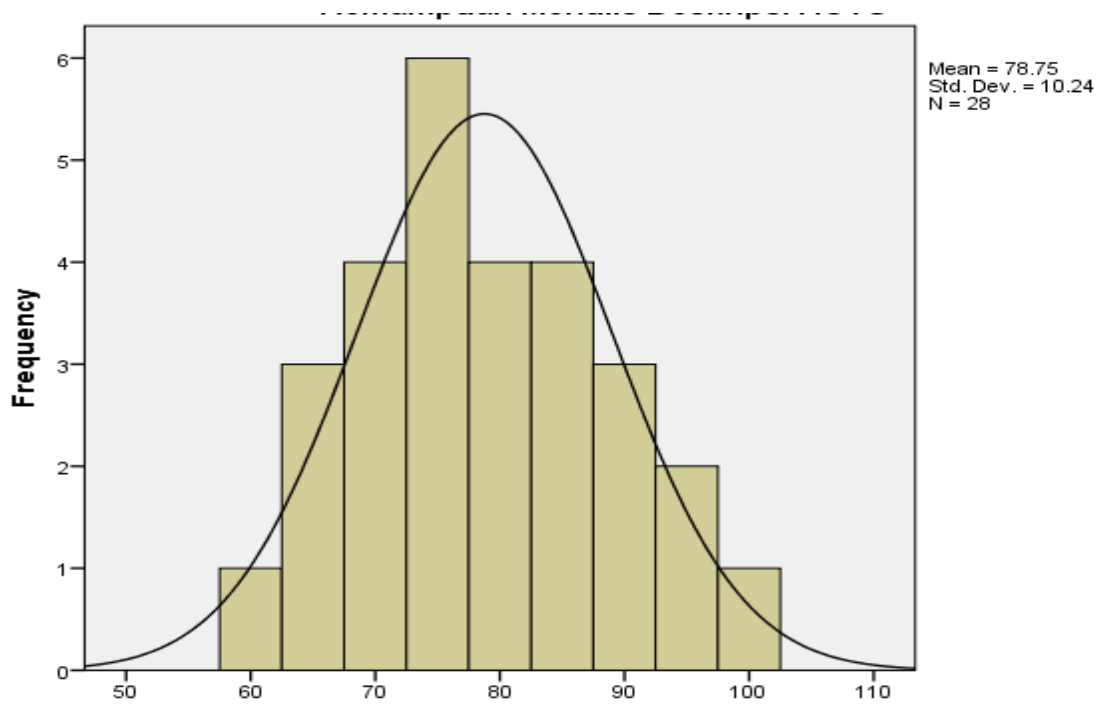

Figure 4. Student Posttest Value Diagram using the HOTS Learning Model

\section{Conclusion}

Based on the results and discussion of the research described in the previous chapter, it can be concluded that:

Learning Indonesian using the Higher Order Thinking Skills (HOTS) learning model through interactive media can improve the students ability to write descriptions of SD Negeri 114361 Binanga Dua, South Labuhanbatu Regency; There is an average difference in the results of the ability to write descriptions of Indonesian using the HOTS learning model and compared to conventional learning models through interactive media in fourth grade students of SD Negeri 114361 Binanga Dua, South Labuhanbatu Regency; From the results of hypothesis testing, the Sig value is obtained. (2-tailed) is $=0.001 ;(0.001<0.05)$ means that Ho is rejected and $\mathrm{Ha}$ is accepted, that is, there is an effect of HOTS learning on students ability to write descriptions. 


\section{BIBLIOGRAPHY}

Desmayani. 2010. Metode dan Srategi Pembelajaran yang Unik.

Yogyakarta: Ar-Ruzz Media.

Karimah, A. H. 2018. Integrasi Higher Order Thinking Skill. Jurnal Program Studi PGMI Universitas Nurul Jadid, 82.

Kuswana, Wowo Sunaryo. 2013. Taksonomi Kognitif. Bandung: PT.

Remaja Rosdakarya.

Sukandi, Ujang. 2001. Belajar Aktif. Jakarta : Pusat Penerbitan Universitas Terbuka.

Trianto. 2010. Mendesain Model Pembelajaran Inovatif-Progresif. Jakarta: Kencana Prenada Media Group. 